\title{
REGIONÁLIS KONJUKTÚRAKUTATÁS EREDMÉNYEI, TAPASZTALATAI
}

\author{
(The experiences of pilot project on regional prosperity analysis)
}

\section{DÖRY TIBOR - LADOS MIHÁLY}

\section{Elözmények}

Az MTA RKK Nyugat-magyarországi Tudományos Intézete (NYUTI) 1996. végén hároméves - az OMFB által támogatott - kutatást zárt le. Az ÉszaknyugatDunántúlon lebonyolított program alapvetō feladata volt egy regionális konjunktúra kutató intézet feladatainak megalapozását segítő vizsgálatok elvégzése és különféle elemzỏ tanulmányok készitése az alábbi területeken: gazdasági prognózisok, marketing- és piacelemzés. Ugyanis a NYUTI kutatási tapasztalatai azt mutatták, hogy a Gazdaságkutató Rt. 1996-tól jelentkező megyei konjunktúra elemzésein kívül nincsenek Magyarországon területi konjunktúra vizsgálatok. A kutatók meggyőzódése volt, amit a vizsgálatok időközben megerősítettek, hogy a gazdaságban a helyi és a regionális piacok felértékelődésével, valamint a térségi szintü fejlesztési programok iránti igény megjelenésével nagy jelentőséget nyerhetnek a régió gazdaságára vonatkozó konjunktúra és versenyképességi értékelések.

Mielött az elvégzett vizsgálatok eredményét, illetve azok tapasztalatait bemutatjuk szükséges annak definiálása, hogy a program során mit értettủnk az egyes kulcsfogalmak alatt, kikre terjedt ki a vizsgálat a vállalkozások méretét, ágazati szerkezetét és területi elhelyezkedését tekintve.

A konjunkturakutatás fogalma alatt a gazdaság fejlödésének, változásának, elmozdulásainak elemzését, prognózisok készitését értettük tanulmányunkban. Ezen vizsgálatok célja, hogy segítse a gazdaság egyes szereplőinek - vállalkozások, költségvetés, háztartások - tervezését, döntéseinek megalapozását. Tartalmilag a konjunktúrakutatás mind a helyzetelemzés, mind a prognózis készítés szintjén két területre osztható, mégpedig a vizsgálatok időhorizontja szerint. Ebben a tekintetben megkủlönböztetünk hosszú (6-20 éves vagy hosszabb idötávú), illetve rövid (negyed évtöl egy évig) és közép távú (1-5 éves) elörejelzéseket.

A konjunktúravizsgálatok, elemzések célja az, hogy olyan konjunktúrapolitikát lehessen megfogalmazni adott régió esetében is, mely az alkalmazott eszközök segítségével képes a konjunktúrahullámzások szélsőségeinek tompítására, vagyis a válság enyhítésére és a fellendülés túlhajtásainak megakadályozására, azaz a gazdaság egészének egyensúlyi állapota közelítéseire a régió szintjén.

A regionális konjunktúrakutatás azonban túlmutat a kormányzati politikát segítő eszköz szerepen. Elsősorban az adott régió vállalkozói számára kell biztositania, hogy döntéseik megalapozását segítse. Továbbá funkciója lehet, hogy a regionális gazdasági önkormányzatok, valamint a Területfejlesztési törvény alapján megalakult 
területfejlesztési tanácsok munkájához nyủjtson támpontokat. Egy harmadik metszete a jelentések régión belüli hasznosulásának a terület attraktivitásának biztositása a külsö befektetök számára.

$\mathrm{Az}$ Észak-dunántúli Konjunktúrakutató Intézet megalapozása program elsö változatai egy három megyés rendszerben gondolkodtak (Györ-Moson-Sopron, Komárom-Esztergom és Veszprém megye). A programterv végül is egy hat megyére - Fejér, Györ-Moson-Sopron, Komárom-Esztergom, Vas, Veszprém és Zala megye vonatkozó egységes minta kialakítását javasolta.

\section{A vállalkozói minták kialakítása}

$\mathrm{Az}$ eredeti elképzelésekhez képest változott a megyék közötti arányok meghatározása. A programterv azzal számolt, hogy a mintában minden megye egyenló súllyal szerepelne, nevezetesen megyénként 500-1000 kis- és középvállalkozás, valamint 25-30 nagyvállalat. A szakmai zsüri megfogalmazta, hogy bizonyos elemzési szempontokat figyelembe véve (pl. ágazati elemzések), a megyénkénti elemzés kicsi elemszámokat ad, ezért javasolta a megyék összevont, "nagy régió" szintü elemzését. Ennek a követelménynek azonban jobban megfelelt, ha a minta figyelembe veszi a területi súlyokat, vagyis a vállalkozások számának megyék közötti megoszlását.

A vizsgálatok során a legalább 300 főt foglalkoztató cégeket tekintettük nagyvállalkozásoknak. A tervezett megyénként egységesen 25-30 vállalkozás megkeresésének koncepciója a szakmai zsüri véleményének figyelembe vételével módosult. Abban az esetben, ha a nagy régiót tekintjük az elsődleges és a megyéket másodlagos elemzési egységnek, akkor szükséges figyelembe venni a nagyvállalkozások egyes megyék közötti megoszlását.

Elözetes felméréseink szerint ${ }^{2}$ a vizsgált régióban összesen 182 cég volt található a konjunktúra hordozó ágazatokban 1995. év végén. Mivel ez az elemszám nagyjából lefedte az eredetileg tervezett mintát, ezért a vizsgálatnak ebben a szakaszában ennek a vállalkozási körnek a teljes lekérdezésére törekedtünk. A nyári idöszak ellenére 59 kérdöív érkezett vissza a kérdező biztosoktól a megadott határidőn belül (1996. augusztus 31.). Ez a tervezettnek közel egyharmada. Ez régió szinten jó reprezentativitásnak felel meg, azonban a megyék között hatalmas aránytalanságok vannak. Györ-Moson-Sopron és Vas megye erősen felül reprezentált, míg a másik négy megyébỏl alig érkezett be kitöltött kérdöiv.

A kutatási terv megyénként 200-250 szervezet közvetlen, illetve további 400-500 szervezett közvetett (direct mail), összesen mintegy 3600-4500 kis- és középvállalkozás lekérdezésével számolt. A futó mintaprogram során használt minta nem csupán egy egyszer lefutó konjunktúra teszt bázisát adja, hanem részben a regionális konjunktúraelemzés következö években müködỏ vállalkozási mintájának kialakítását, részben pedig különböző lekérdezési és mintavételi módok tesztelését is szolgálta. Így az elözetesen megálmodotthoz képest valamelyest változott a lekérdezés nagyságrendje, továbbá a módszer alkalmazása szerint az egyes megyékben alkalmazott minták nagysága is eltéróen alakult.

A legmegfelelöbb mintát Györ-Moson-Sopron megyében sikerült összeállítani. A kamarai adatbázisra támaszkodva, az előzetesen meghatározott feltételeknek 1490 
vállalkozás felelt meg és összesen 237 feldolgozható kérdőív (16,0\%-os visszaküldési arány) érkezett vissza a megyéböl. Zala megyében a kamara által megadott címlista alapján a NYUTI Szombathelyi Csoportja postázta ki a kérdöíveket, amelyekből 109 kitöltöttet küldtek vissza a vállalkozások, ami 7,3\%-os aránynak felel meg. Komárom-Esztergom megyében szintén a helyi kamara állitotta össze a mintát és a kamarai újsághoz csatoltan küldték ki a tagok részére. Itt 91 értékelhetö kérdöiv futott be, ami 6,1\%-os beérkezési arányt jelentett. Fejér megyében a Vállalkozásfejlesztési Alapítvány bonyolította a lekérdezést és annak ellenére érkezett csak 59 kitöltött kérdőiv (3,9\%), hogy azon vállalkozások kapták meg, akik valamilyen módon kötődnek az alapítványhoz. Vas megyében kérdezö biztosok járták végig a vállalkozásokat, korábbi évek lekérdezése alapján, amelynek eredményeképpen a 400 címböl 151 esetben $(37,8 \%)$ volt sikeres az adatszolgáltatás. Veszprém megyében 500 vállalkozás közvetlen lekérdezése történt 100\%-os hatásfokkal, azonban még a kérdőiv véglegesítése előtt, így inkompatibilitása miatt elemzéseinket Veszprém megye nélkül végeztük.

\section{Az Észak-Dunántúl gazdasági kilátásai 1996. 1. félévének tükrében - Nagyvállalatok}

Hangsúlyoznunk kell a NYUTI által elvégzett konjunktúrakutatás pilot-projekt jellegét, hiszen az elkészült konjunktúra jelentés eseti jellegủ megállapításokat is tartalmaz, idősorok hiányában mélyebb elemzéseket nem állt módunkban végezni. A továbbiakban - a technikai részletek és a kevésbé lényeges megállapítások mellözésével - közreadjuk a nagyvállalkozások gazdasági kilátásait feltáró részét, hiszen terjedelmi korlátok miatt nem tudunk kitérni a kis- és középvállalkozói kérdöív eredményeire, amelynek ismertetése szintén egy önálló cikket érdemel.

\subsection{A minta szerkezete}

A megadott határidőn beluil 59 kérdőív futott be a kérdező biztosoktól. Ezt követően került sor a feldolgozásra. Ennek megfelelóen a nagyvállalati minta $73 \%$-a Győr-Moson-Sopron és Vas megyei szervezetekből állt össze. A jogi forma szerinti szerkezetról elmondható, hogy a régió egészét tekintve azonos arányban voltak kft és rt formában múködö társaságok, valamint 4 szövetkezet is válaszolt.

A foglalkoztatottak száma volt az egyik lényeges kiválasztási szempont, hogy mely vállalkozások kerültek a nagyvállalatok közé. Arra törekedtünk a minta meghatározásánál, hogy a 300 fö feletti vállalkozások véleményét ismerjủk meg, de a megkérdezettek 22\%-a (13 vállalat) a lekérdezéskor kevesebb, mint 300 fót alkalmazott, többségük 300-500 munkavállalónak adott munkát, csak a Rába Rt és a Dunaferr Kft foglalkoztatott 3000 fönél többet.

Az árbevételt tekintve az 1 milliárd, illetve az 1-5 milliárd forint éves árbevételü cégek domináltak, kisebb arányban ugyan, de a mintába kerültek magas, 5-10, valamint 10 milliárd forintot meghaladó forgalmat realizáló vállalatok is. A kategóriák már a feldolgozás során kerültek meghatározásra, a kérdőívben az árbevétel összegére kérdeztuink rá. Úgy igyekeztük a mintát kialakítani, hogy az reprezentálja az adott megye gazdasági szerkezetét, legalábbis a megye 
gazdaságának jelentösebb vállalatai szerepeljenek benne. A régió tradicionális iparágai, a gépipar és a textilipar alkották a megkeresett vállalatok gerincét, összesen $43 \%$-át, amit az élelmiszeripar (16\%) és a kereskedelem (16\%), majd az építő- és építőanyag-ipar (12\%) követett.

A cégek tulajdonosi szerkezete meglehetősen vegyes képet mutat, mert a tulajdonosok között a lehetséges összes típus előfordult. Nehéz egyértelmü választ adni arra, hogy melyek a dominánsak a mintában, hiszen a gyakorlat szerint ma már a társaságoknak legritkább esetben van csak egyetlen tulajdonosa. Legtöbbször hazai társaságot (31), hazai magánszemélyeket (22) és a dolgozói tulajdont (21) nevezték meg, de a tulajdoni arányok tekintetében a még mindig domináns állami tulajdon (13) mellett, külföldi társaság (18), illetve magánszemély (5) volt a meghatározó.

\subsection{Az értékesitési és beszerzési kapcsolatok értékbeni alakulása}

$\mathrm{Az}$ export tevékenységból származó bevételek változása az 1995-ös évhez viszonyítva 1996-ban mintegy 29,9\%-kal növekszik, míg a következő esztendóben a kérdésre választ adók csupán 13,9\%-os bővülésröl számoltak be. Sajnálatos azonban, hogy ezen átlagos érték mögött volumenét tekintve 11\%-kal csökkennek majd a várakozások szerint az árukiszállításokból származó vállalati jövedelmek (1. ábra). A kissé borús képet színesíti azonban az a néhány vállalkozás, amely az átlagot jóval meghaladó (több, mint 100\%-kal) módon tervezi növelni exportját.

$\mathrm{Az}$ exporttal szembeállitva az import beszerzéseket elmondható, hogy azok volumene csak mintegy fele az exportból származó vállalati bevételeknek, tehát a mintába vont vállalkozások nettó exportőrök, évente közel 250 millió dolláros aktívummal. Az import folyamatok mértéke 1996-ban dinamikusabban változott, de 1997-re itt is enyhe visszaesés várható. A vállalati szerkezetet tekintve jelentős eltérések tapasztalhatók ezen belül, hiszen az import bővülés átlagos mértéke meghaladta a $83 \%$-ot.

Figyelemre méltó mértékben növekedett, illetve a várakozások szerint növekedni fog a vállalkozások árbevétele, 25,5\%-kal haladja meg az elmúlt évben realizáltakat. Ezzel szemben a vállalatvezetők prognózisa 1997-re nézve kevésbé optimista, mindössze 3,3\%-os bővülést remél.

$\mathrm{Az}$ árbevétellel közel azonos mértékben várható a termelési érték változása, azonban annál alacsonyabb mértékben nö. Itt is számottevó az 1997-re várt növekedés dinamizmusának csökkenése, mindössze 2,2\%-kal emelkedik majd.

A nyereség vonatkozásában még az eddigieknél is sokkal óvatosabban nyilatkoztak a megkérdezett vállalkozások. Eszerint meglehetősen nagy mértékben $(20,4 \%)$ fog visszaesni a nyereség a következö évben az 1996-os esztendőhöz viszonyítva. 


\author{
1. ÁBRA \\ Az értékesitési és beszerzési kapcsolatok értékbeni alakulásának változása \\ (1996/95 és 1997/96) \\ Transition of the values of sales and purchase connections \\ (1996/1995 and 1997/1996)
}

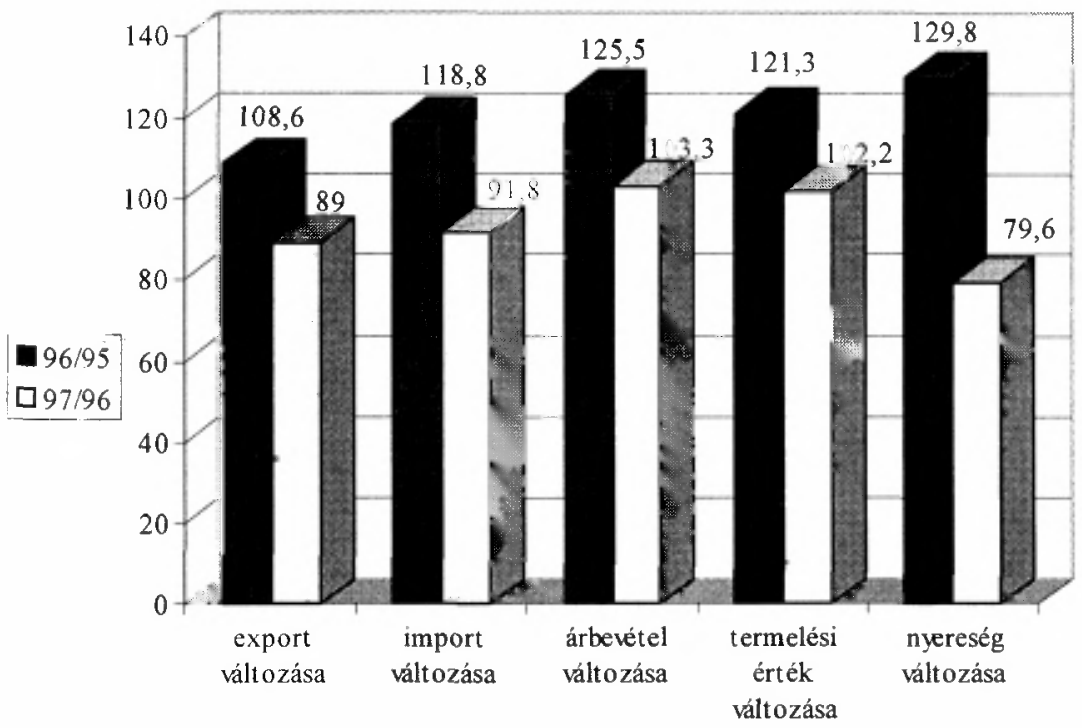

Forrăs: Nagyválialati kérdőívek, 1996

A helyi piacok jelentóségét a vállalkozások $43,9 \%$ úgy tekinti, hogy az nem fog jelentősen változnia az elkövetkező három évben, 24,6\%-uk szerint növekszik majd jelentőségük. Meghatározó hányaduk (17,5\%) véleménye azt tükrözi, hogy ezen piaci szegmensnek nincs jelentósége, amit az magyarozhat, hogy a felmérésbe került nagyvállalatok alapvetően nem a helyi piacra termelnek, termékeik inkább hazai és nemzetközi piacokon találnak vevöre. Azt mondhatjuk, hogy a 300-500 fö közötti, 1-5 milliárd árbevételü, döntően gépipari szervezetek számára van jelentősége a helyi piacnak.

$\mathrm{Az}$ elózőekben vázoltak hasonlóan igazak a megyei és a regionális piacok megítélésével kapcsolatosan is. Ezen piaci típusok elkövetkezỏ évekbeli jelentóségét semlegesnek, illetve kis mértékben meghatározónak tekintik a helyi piacoknál már tipizált vállalkozások. 


\subsection{A foglalkoztatottak számának alakulása}

A foglalkoztatott létszám tekintetében kis mértékü $(2,7 \%)$ növekedésre számítanak a megkérdezett vállalatok 1996-ban, ami azonban már nem mondható el a következő évre. Ha csupán a kérdésre választ adókat tekintenénk, úgy a foglalkoztatottak számának 7,3\%-os csökkenését prognosztizálhatnánk, ami azonban nem teljesen fedi a valóságot, hiszen a mintából 5 vállalat 1997-re nem adott meg várható létszámadatot. Az ebböl adódó torzítások elkerülése végett interpolációval becsült adatokra támaszkodva - kedvezöbb képet nyertünk, így a visszaesés mértéke már csak $1,0 \%$ volt. A kapott válaszok azt mutatják, hogy a jelentösebb leépítéseket az élelmiszer,- az épitö- és építőanyag-iparban, valamint a gépiparban jelezték a vállalatok.

A foglalkoztatottak szakképzettség szerinti változására jellemzö a kevésbé kvalifikált alkalmazottak, betanitott és segédmunkások létszámának csökkenése ($0,4 \%)$, valamint a szakmunkások és a felsőfokú végzettségüek $(+0,5 \%)$ iránti kereslet növekedése. A változás mértékét azonban árnyalja az a tény, hogy nem mindegyik vállalat adta meg a foglalkoztatottak szakképzettség szerinti bontását, így a kapott eredményt fenntartással kell kezelni. Ha a gazdasági folyamatokat ezzel párhuzamba állítjuk, úgy reálisnak tủnhet a megadott változás iránya, mértékének nagysága azonban attól eltérỏ lehet.

Megállapítható, hogy a nyelvvizsgával rendelkezö munkatársak száma az ágazatok mindegyikében rendkívül alacsony, átlagosan a dolgozók 1,85\%-ának van államilag elfogadott nyelvismerete. Ezen szempontból a megkérdezett vállalatok között nincs nagy különbség, kiugróan sok idegen nyelvet beszéló szakembert sehol sem foglalkoztatnak, söt hat helyen egyáltalán nincs idegen nyelvismeretet vizsgával igazolni tudó munkatárs. Egyetlen esetben tapasztalhattuk csupán 11\%-nál magasabb arányt, amely azonban kifejezetten német érdekeltségủ vállalat.

\subsection{Az értékesitési árak alakulása}

$\mathrm{Az}$ értékesítési árak mértékére vonatkozólag visszafogottan nyilatkoztak a vállalatok, ami azt jelenti, hogy nem terveznek - saját bevallásuk szerint - a hivatalos inflációs rátánál nagyobb mértékủ áremelést, többségük (46\%) $10-20 \%$ közötti áremelést jelez, sőt további 22\%-uk 10\%-nál alacsonyabb mértékben emeli árait (2. ábra). Figyelemre méltó, hogy döntően textilipari cégek egyáltalán nem prognosztizálnak árnövekedést, míg zömében élelmiszeripari vállalatok valószínüsítenek 20-30\%-os drágulást. Érdekes, hogy mintába vont vállalkozások e feletti értékesítési áremelést nem céloztak meg.

$\mathrm{Az}$ ágazatokat tekintve kiemelendö a textilipar alacsony árnövekedési indexe, de a gépiparban, illetve az épitỏ- és épitőanyag-iparban sem jellemző az árfelhajtás, ami azt jelentheti, hogy a jövedelmezőbbnek ígérkező exportból igyekeznek kompenzálni a belföldi piacokon elmaradó jövedelmüket. 
Tér és Társadalom, 11. 1997. 1. 283-296. p.

\section{2. ÁBRA}

Az értékesítési árak változása

Transition of the sales prices

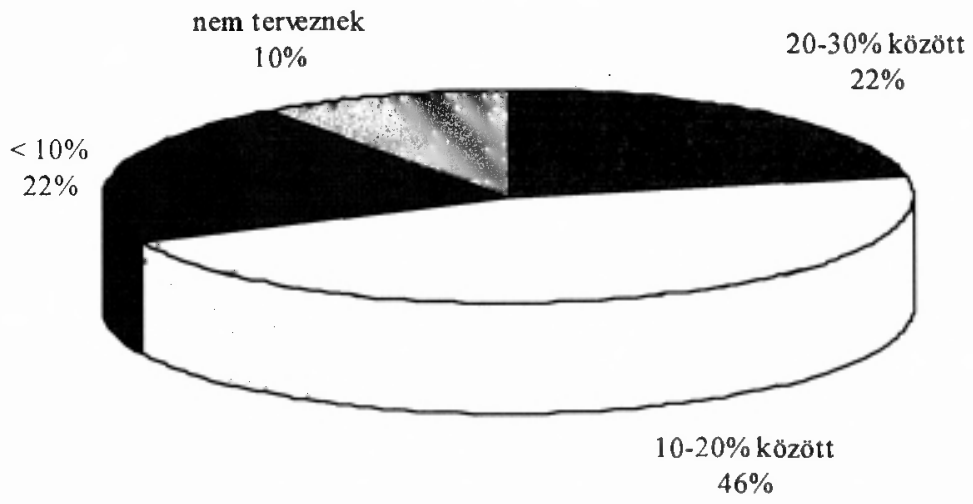

Forrảs: Nagyvállalati kérdőívek, 1996

\subsection{A vállalat és a gazdaság helyzetének megítélése}

A vállalkozás és a magyar gazdaság kilátásainak megitélése 1997-ben minden területen kedvezőbben alakul, mint 1996-ban - 1995-tel való összehasonlítása alapján. A legdinamikusabb javulást a FÁK-piacain $(10,8 \%)$ és a nyugat-európai piacokon $(8,2 \%)$ várnak a megkérdezettek.

A vállalat helyzete a megyében az ötfokozatú skálán a három évben 3,89-os értéket kapott, ami az egyes felsorolt tényezök között a legmagasabb és leginkább megközelíti a megfeleló szintet. Néhány századdal, illetve tizeddel marad el ettől a vállalat és az ágazat régióban és az országos összehasonlításban betöltött szerepének értékelése. A helyzetelemzés világméretü kitekintésben azonban már "rossz" és a "nagyon rossz" ítéletet kapta és ellensúlyozza a helyi és regionális szintủ optimizmust.

Hasonló igaz az ország gazdasági megítélésére is, amelyet a vállalatok - adott válaszaik alapján - rossznak tartanak. 


\subsection{A vállalatok gazdálkodását akadályozó tényezők}

\subsubsection{Vállalati belsỏ tényezök}

A kérdöívben említett akadályok közül leggyakrabban a magas anyagköltséget $(3,19)$ és a rendelkezésre álló saját források hiányát $(3,07)$ nevezték meg, de a lényeges gátló tényezőkhöz soroltảk az elöregedett, korszerútlen gépállományt is. A magas hitelállomány, a vállalati marketing hiánya kismértékben gátolja a vállalkozások növekedését, azonban saját bevallásaik szerint kihasználatlan kapacitásaik nem állják fejlỏdésủk útját és nem jelent kiugró problémát a beszállítók elẻ támasztott minőségi kővetelmények kielégítése és a szállítási határidók betartása sem, ami azonban megítélésünk szerint megkérdöjelezhető, talán kicsit jobb színben látják a megkérdezettek a vállalkozói környezetet.

\subsubsection{Piaci tényezỏk}

A vállalkozás gazdálkodásának akadályozó tényezői között a piaci tényezők játsszák a legkisebb mértékü szerepet, amelyek közủl a piaci lehetőséget hiánya és a versenytársak miatti konkurencia a meghatározó. Figyelemre méltó, hogy a megkérdezettek számára a fogyasztói igények változása egyáltalán nem akadály, amit úgy is mondhatunk, hogy tudják követni az igények változását.

\subsubsection{Kormányzati politikától függö tényezỏk}

Nem mondhatunk újat azzal a közhelyszerú kijelentéssel, hogy a vállalkozások magasnak tartják a kormányzati adók és illetékek mértékét és bizonytalan helyzetben érzik magukat a szabályozók évenkénti - már-már állandósuló változása miatt. Megítélésủk szerint a hosszú(abb) távú tervezéshez elengedhetetlenúl fontos gazdasági és jogi környezet folytonosságát kellene megteremteni. A vállalkozások megtérülési rátájával vetekedő hitelkamatok szintje és a vállalkozás támogatás jelenlegi rendszere is a komoly akadályok kỏzé tartozik.

\subsubsection{Helyi/regionális tényezók}

A helyi/regionális feltételek értékelését két csoportra oszthatjuk: a munkaerố kinálattal, illetve a telephellyel összefüggö tényezők. Fontosnak tartjuk kiemelni, hogy a vállalkozások megítélése szerint az Észak-Dunántúlon, különösen GyőrMoson-Sopron és Vas megyében magasak a bérköltségek, - természetesen beleértve annak közterheit ${ }^{3}$ - akadályozó tényezó lehet (egyes szakmákban esetleg már az is) a munkaerö-kínálat nem megfelelö mennyisége és kiemelten a minősége.

A telephelyi tényezóket tekintve magasak a helyi adók, a szakemberek még nem érzik a központi adóztatás helyi szintre való hangsúlyeltolódásának szükségszerüségét, azt csak újabb adóztatási formának tekintik. Kisebb mértékben ugyan, de a helyi infrastruktúra, a szállítási kapcsolatok is a fejlődés gátjai.

\subsubsection{Nemzetközi tényezök}

Kisebb mértékben befolyásolják a vállalkozások növekedését a nemzetközi feltételek is, amelyen belül leginkább korlátozók a nemzetközi vámegyezmények elöírásai, az eltérő szabványok, minőségi elóírások. A keleti piacok elvesztésével, a délszláv konfliktus elhúzódásával, valamint a közép-kelet-európai térség 
kedvezötlen megitélésével szemben közömbösnek mutatkoztak a megkérdezettek. Ausztria EU-belépését feltünö módon semlegesnek itélték az érintettek.

\subsection{A vállalkozások vagyoni helyzetének változásai}

A válaszadók többsége (79\%) szerint jelentősen nőtt, vagy egyszerủen csak nött az elmúlt három évben cégük vagyona, míg csökkenéséről, jelentős csökkenéséről csupán 7\%-uk tett emlitést, fennmaradó hányaduk pedig annak változatlanságáról számolt be.

Jelentős növekedést gép-, textil és vegyipari vállalatok érték el, ugyanakkor a vagyoncsökkenéstól érintett szervezetek többsége is a gépiparból került ki. A vagyoncsökkenés okait és módját fürkészve csak elvétve kaptunk választ, így a kérdés ezen felét nem tudtuk értékelni.

A vállalatok vagyonnövekedésének módja új üzletág nyitásával, új technológia bevezetésével, új telephely létesítésével, valamint kapacitásbővitéssel történt, de a nevezett okok között inegtalálható volt az exportbővités, a felesleges tőke pénzügyi befektetése, illetve a tulajdonosoktól függő tőkeátadás is. Érdekességként említhetjük meg a energiatakarékosságot is, mint vagyonnövelö tényezöt, illetve a "nem fizetek társasági nyereségadót és növelem az eredménytartalékot" megoldást.

Az elkövetkező időszakban tervezett vagyonnövekedés a realizálthoz hasonlóan fog alakulni és a többszörös megjelölés lehetősége miatt markánsabban fejeződött ki az új üzletág nyitásának, új technológia bevezetésének és a kapacitásbővítés jelentősége.

\subsection{Magyarország EU-csatlakozásának jelentősége}

Egyértelmüen pozitív képet tükröz hazánk EU-csatlakozásának megitélése, amit nem tompít a közömbös, illetve semleges hatásról beszámoló néhány vállalat. A többség számára a piaci lehetôségek javulása, a külpiacokra jutás egyszerüsödése és a piac bövülése jelenti az igazi előnyt. Szerintük nőhet a magyar gazdaság és egyben az ország vonzereje, a csatlakozás elökészítése során pedig egyre eröteljesebben fogalmazódnak meg a minőséggel és a környezetvédelemmel kapcsolatos követelmények. A föként exportra dolgozó cégek azonban nem fogadnák kitörö lelkesedéssel a vámok lebontását, amely a piaci védettség megszünésével és fokozódó versennyel járna. Ezt egyébként a csatlakozás előnyösségét hangsúlyozók is kiemelték.

A megyében, illetve a térségben jelenleg is meglévő előnyöket kihasználva erőteljes fejlódés indulhat meg, ami a befektetések, ipartelepítések során a foglalkoztatás bỏvülésében, a jövedelmek növekedésében jelenik meg. Hátrányként fogalmazódott meg, hogy az itt múködö vállalkozásoknak fokozódó versennyel kell számolni, valamint várható a mezögazdaság hátrányos helyzetbe kerülése.

\subsection{A vállalat fejlesztésének fóbb irányai}

A jövőépités szempontjából meghatározó az új termékek, szolgáltatások bevezetése, a beruházások megvalósitása mellett az új piacokon történő megjelenés, illetve az ezt támogató marketing akciók, programok eredményes végrehajtása. A preferencia sorrendben elökelö helyen szerepelt a meglévö kapacitások bővítéséhez kapcsolódóan, az eszközpark energiatakarékos gépekre, berendezésekre való 
cseréje, esetenként átalakitása. Az vállalat fejlesztése során igénybe veendő területek leginkább a termelés infrastrukturális környezetétét érintették, úgymint az információáramlás javítását, erőteljesebb reklámtevékenység folytatását a régióban és ennek következtében az új piacokra való behatolást. A vállalatok kevésbé hajlanak a nyersanyagok másodlagos felhasználására és a hulladékhasznosításra, valamint visszafogottak új telephelyek, mühelyek létesítésében is. Ezt megerősitendő, legtöbbször nevezték meg az épület és telephely bővítését és a vállalatok egyelöre nem szándékoznak tevékenységưket diverzifikálni, ủj üzletágak nyitásának kockázatát felvállalni.

\subsection{Beruházások}

A vállalat fejlesztési irányainál megállapítottuk, hogy a vállalkozások kevésbé hajlamosak nagyobb invesztícióra, inkább meglévő kapacitásaik kihasználását igyekeznek fokozni, illetve minőségileg fejleszteni. A beruházások tárgyát tekintve leginkább termelési eszköz beszerzését (13 megnevezés), új üzemcsarnok építését (10 megnevezés) tervezik. 7, illetve 6 említés szól technológia és épület korszerủsítésröl, bővítésről, míg 5 vállalat önálló uuzletet/irodát kíván létesíteni. Elgondolkodtató, hogy az 57 vállalatot tartalmazó mintából csupán 4 esetben regisztrálhattuk új termék piacra vitelének szándékát. Ezek után már nem meglepö a környezetvédelem és az energia-megtakarítás melletti elkötelezettség beruházásokban kifejezỏdő hiánya, ami a vállalatok töredékénél (3-3 vállałat) jelent csak meg.

A tervezett beruházások összvolumene majdnem megközelíti a 27 milliárd forintot, (pontos összege: 26.988 millió Ft), amelyet 47 projektról nyújtott információ alapján összesíthettünk. Jelentős eltérések mutatkoztak azonban emögött, hiszen megtalálható volt a mintában a 10 milliótól egészen a 7,5 milliárd forintig terjedö nagyberuházás is. A befektetéseik jellemzőit áttekintve (1. táblázat) szembetünö a 100-500 millió forint közöttiek túlsúlya, amelyeket már a fajsúlyos fejlesztések közé sorolhatjuk, az 500 millió forint feletti 5 invesztíciót pedig nemzetgazdasági jelentőségünek minősíthetünk.

A foglalkoztatottak számát a beruházások következtében összesen 1495 fövel tervezik növelni a megkérdezettek, amelynek projektenkénti átlaga 43,9 fö, de elöfordult a beruházással (racionalizálás) kapcsolatos munkaerö-leépités lehetösége is. Annak ellenére, hogy legnagyobb számban 0-10 fö között növelik a cégek a foglalkoztatottságot, előfordul - a nagybefektetéseknél - 450, 600 fö újonnan történő munkába állítása (1. táblázat) is.

1. TÁBLÁZAT

A befektetések jellemzöi

Characteristics of the investments

\begin{tabular}{|l|c|l|c|}
\hline \multicolumn{2}{|c|}{ Beruházás összege } & \multicolumn{2}{c|}{ Tervezett létszámbỏvités } \\
\hline \multicolumn{1}{|c|}{ kategória (Ft) } & emlitések száma & \multicolumn{1}{c|}{ kategória (fö) } & emlitések száma \\
\hline 100 millió alatt & 17 & $0-10$ fö között & 17 \\
\hline $100-500$ millió között & 26 & $10-50$ fö kózött & 10 \\
\hline 500 millió felett & 5 & 50 fó felett & 5 \\
\hline
\end{tabular}

Forrás: Kérdőívek 


\subsection{Telephelyi tényezök}

A telephelyi tényező́k fontosságának aktualitását az Észak-Dunántúlon koncentráltan jelentkező külföldi töke megjelenése adja, így nem tekinthetünk el az egyes jellemzők minősítésétől, hiszen ezáltal válik láthatóvá, láthatóbbá, hogy az országban miért éppen itt ruháznak be Budapestet követỏen a legtöbbet.

\section{Munkaerö}

A vállalatok szempontjából legfontosabb, az adott szakirányra rendelkezésre álljon a képzett munkaerö $(4,00)^{4}$, és természetesen szükséges számban $(3,65)$, ezzel szemben kevésbé fontos a munkaerő területi megoszlása $(2,76)$. Kiemelt jelentőséget tulajdonítottak a vállalatvezetők az új ismeretek fogadási készségének $(3,88)$, a munkakultúrának és a termelési tapasztalatoknak $(3,78)$.

\section{Közlekedés, kommunikáció}

Az infrastrukturális jellemzők közül a telefonnal való ellátottság színvonala $(4,36)$, és a közúti közlekedési kapesolatok $(4,29)$ kapta a legjobb minösitést, mellyel szemben Bécs elérhetösége (ami ma már nem probléma) $(2,40)$ és a vasúti közlekedési kapcsolatok $(2,71)$ a kevésbé lényeges tényezök.

Fogadási és támogatási feltételek

A beruházásokat végrehajtó és azt tervezö vállalatok számára legfontosabb az új beruházások infrastrukturális fogadási feltételei $(4,04)$, a helyi adókedvezmények $(3,65)$ és adók mértéke $(3,65)$ és érdekes módon az utolsó helyen szerepel a letelepedést segitö szervezetek (pl. közjogi kamarák) megítélése.

Helyi, térségi piac

A helyi és a térségi piac a megkérdezett vállalatok számára kevésbé lényeges, inkább közömbös; hiszen tevékenységük jellegéböl adódólag számukra jelentősebbek a magyar és a nemzetközi piacok. Ebben a tekintetben a helyi és a térségi piacokért való versenyt emelték ki $(3,22)$ és a közösségi megrendeléseket (önkormányzati, költségvetési) $(2,41)$ nem tartották fontosnak.

\section{A fejlesztést, a megújitást szolgáló helyi, térségi intézmények}

A munkaadók számára, a termelés megfelelő színvonalon való elvégzéséhez a nyersanyagokon kívüI az emberi erőforrásnak van a döntö szerepe, amelynek szellemében számukra a képzettség színvonala meghatározó. Így a szakmai képzést $(3,50)$ és a menedzsment (tovább)képzését $(3,32)$ részesítették elönybe a szakemberek. A fejlesztést hordozó $\mathrm{K}+\mathrm{F}$ intézmények $(2,51)$ és $\mathrm{K}+\mathrm{F}$ információkat kínáló szervetek szolgáltatásai $(2,55)$ iránt csak minimális igény mutatkozott.

\section{Településhálózat és életkörülmények}

A vállalatok ebben a blokkban is hangsúlyozták a kommunális infrastruktúra $(4,29)$ kiemelt szerepét, valamint a helybeli vagy gyorsan elérhetö pénzügyi szolgáltatások $(3,82)$ és a közbiztonság $(3,62)$ jelentőségét. Úgy tünt, a kulturális és 
szórakozási feltételek $(2,37)$ és a lakáskínálat minőségi összetétele $(2,82)$ még nem foglalkoztatja a nagyvállalatok vezetőit.

A legjobb telephelyi tényezók közül a munkaerőt költségét, minőségét, a rendelkezésre álló szakemberek számát, némelyek viszonylag alacsony árát tekintik, - a már egyre jobban kiépülö infrastruktúra (elsösorban a jó szállítási kapcsolatok miatt - Ml-es autópálya, vasút) mellett - a térség legföbb vonzerejének. A nevezett "kemény" tényezókhöz párosítva némely esetben már a "puha" tényezök, mint az új ismeretek fogadási készsége, az újra való fogékonyság, a munkakultúra is kifejezésre jutott.

A kevésbé megfelelönek tartottak közé sorolták - érdekes módon - a legjobb tényezökkel párhuzamosan a bizonyos szakmákban a kellő számban rendelkezésre nem álló munkaeröt, a helyi adók, az adókedvezmények mértékét és az ingatlanárak magas szintjét. A rendkívül sokféle, rossz telephelyi jellemző között található még a müszaki fejlesztést segítő kutató-fejlesztő intézmények hiánya, vállalkozások beruházásait támogató pénzeszközök szükössége, valamint a nehézkes önkormányzati ügyintézés és fogadókészség.

\subsection{A fejlesztést szolgáló feladatok és intézmények}

A vállalatok értékelése szerint kiemelt jelentőségü a megyére vonatkozó területfejlesztési stratégia kidolgozása és a stratégiához rendelt decentralizált pénzalapok létesítése, amelyek a feltétlenül kialakítandónak tartott feladatok rangsorában az elsỏ két helyre kerültek. Alig marad el ettől a vállalatok emberi erőforrás fejlesztését szolgáló szakmai képzés, át- és továbbképzési programok prioritásként kezelése. A nem fontos, de nem is közömbös tényezők közzé soroltatott a megyearculat egységesitése, a megyekép kialakítása és terjesztése, a kistérség-fejlesztési koncepciók kialakítása. A vállalatok oldaláról fontosabbnak ígérkező piackutatással, értékesítési lehetőségek feltárásával foglalkozó ügynökség létrehozása, a gyorsan elérhető vállalkozásfejlesztési tanácsadás iránti érdeklődés hiánya azt jelezi, hogy a nagyvállalatok ezt saját kereteik között oldják meg, ezeknek az intézményeknek a célcsoportját a kis- és középvállalkozások jelentik.

\subsection{Kutatás-fejlesztési tevékenység}

Arra a nagyon egyszerü és könnyen megválaszolható kérdésre, hogy a vállalat folytat-e valamifajta kutatás-fejlesztési $(\mathrm{K}+\mathrm{F})$ tevékenységet a megkérdezettek $63 \%$ a egyértelmü nemmel felelt. Ez különösen a termelö vállalatok esetében szomorú, hiszen ebböl arra következtethetünk, hogy csupán régi termékeiket gyártják, vagy bérmunkát folytatnak, ami semminemú helyi fejlesztést nem igényel.

Ha a $\mathrm{K}+\mathrm{F}$ területen foglalkoztatottak számát tekintjük akkor sem kedvezóbb a helyzet, mert kiderül, hogy a saját bevallásuk szerint $\mathrm{K}+\mathrm{F}$-et folytatók sem kimondottan helyeznek erre a területre hangsúlyt. Megdöbbentően alacsony az egy vállalaton belül, ezen a területen dolgozók száma, ami az igennel válaszolók $80 \%$ ánál kevesebb, mint 10 föt jelent. Jelentősnek tekinthetô fejlesztési részleggel a minta két vállalata rendelkezik 65, illetve 330 fövel. Ehhez azonban lényeges 
Tér és Társadalom, 11. 1997. 1. 283-296. p.

megjegyezni, a vállalat nagyságából adódóan ez a viszonylag magas létszám sem haladja meg az összes foglalkoztatott $0,5-1 \%$-át.

$\mathrm{Az}$ évente K+F-re fordított összeg mértéke - az elözökkel összhangban meglehetősen alacsony, a termelési költségek 1-2 százalékát teszi ki jobb esetben, de találkozhattunk tizedszázalékpontos fejlesztési ráfordításokkal is. Értékét tekintve pár millió forinttól a 100-300 millió forintig terjed.

A magyar gazdaság jelenlegi állapotáról borús képet fest, hogy a vállalatok nagyobb hányada (esetünkben 56\%-a) az elmúlt három évben egyáltalán nem fejlesztett ki új terméket vagy eljárást. Az újonnan létrehozottak között is kevés az igazi innovatív termék. A kifejlesztett gyártmányok zömmel a korábban gyártottak módosított változatai és csak kis számban találhatunk valóban új, a piacon megjelenéséig nem található terméket.

A fejlesztési szándékok után fürkészve az előzőekhez hasonló helyzettel találjuk szemben magunkat, mert éppolyan kevés helyen vették tervbe új termék, eljárás kifejlesztését az elkövetkezó három évben is, mint az azt megelözö idöszakban. Konjunkturális szempontból ez azt jelenti, hogy a közeljövőben sem fog megújulni a vállalatok tömegénél a termékszerkezet, kisebb jelentőségü fejlesztésekkel pedig csak apró eredményt lehet elérni, jó ha nem szorulnak ki - az egyre több konkurenssel megvívandó harcban - a piacról. Ebböl a szempontból lehet veszélyes és figyelemfelkeltô, hogy a kifejlesztett termékek, eljárások részesedése rendkívül alacsony az árbevételen és legföképpen az exporton belül, csupán 8 vállalatnál haladja meg a 10 százalékot. Pozitív példaként létezik olyan szervezet is, ahol a kifejlesztett termékböl való árbevétel meghaladja a 30, illetve a 35\%-ot.

Az 57 vállalatra kiterjedö vizsgálatban mindössze két(!) esetben számoltak be saját találmány vagy más szellemi termék értékesítéséröl, ha pedig azok volumenét, jelentőségét figyeljük, úgy az értékesítésükért kapott 600 ezer, illetve 1 millió forint meglehetősen minimális összeg a vállalatok által realizált árbevételböl való részesedése tekintetében. Hasonlóan kevés cégnél ( 8 emlités) nyilatkoztak licensz vásárlásról, ami pedig a technikai, technológiai megújulás alapjául szolgálhatna. Ezek is vegyes vállalatok vagy döntően bérmunkát folytató szervezetek voltak, ahol a termelési kultúra meghonosítása nem járt további fejlesztésekkel, csupán az otthon megszokott, esetleg kifutóban lévő eljárások magyarországi adaptációját jelentette. A vásárolt licenszek eredete magyar (2), német (2), angol, belga, japán és svájci (1-1) illetöségü volt.

A vállalatok termékeinek/termékcsoportjainak életkora nagyon magas, átlagosan megközelíti a 15 évet. Mindössze hat esetben gyártanak 1 évnél fiatalabb terméket. $\mathrm{Az}$ életkorból következöen a gyártmányok túlnyomó többsége az érettség, illetve a hanyatlás stádiumában található.

Felsőoktatási intézményekkel, kutatóintézetekkel a megkérdezettek 35\%-a tart fenn kapcsolatot, amelynek típusa eseti megbízás, fejlesztési egyuttmüködés vagy éppen valamely probléma vizsgálata. A kapcsolatok intenzitása rendszeres, konzultációs jellegư, amelynek kialakulása (pár kivételtỏl eltekintve) az 1990-es évek kezdete óta tart.

A fejlesztési elképzelések megvalósításához a vállalatok csak szerény mértékben kaptak állami támogatást. A támogatási forrásokat szétosztó szervezetek közul az OMFB nyújtotta a legnagyobb összegüt, de az Ipari és Kereskedelmi Minisztérium 
kereskedelem-fejlesztési és exportösztönzési támogatásai nagyságrendben nem sokkal maradtak el ettől. A vállalatok gazdasági súlyát, potenciális fejlesztési lehetöségeit mérlegelve azonban a támogatások összege a minta vállalatai által tervezett beruházásokhoz képest is minimális, nem éri el annak egy(!) százalékát.

\section{A regionális konjunktúrakutatással kapcsolatos további teendők, tapasztalatok}

A lefutott program alapján újra kell értékelni a kérdőívek hatékonyságát, módosítani vagy el kell hagyni a nem müködő részeket. Újra kell gondolni a program infrastruktúráját, mind a humán (belsö és külső eröforrások), mind a technikai háttér (hardver, szoftver, nyomda, postázás) tényezők tekintetében. Továbbra is szükséges a külsö szakmai partnerekkel való kapcsolatépítés. A program know-how-ját biztosító osztrák intézet mellett fontos lenne a hazai nagy konjunktúrakutató mühelyekkel való kapcsolat felvétel, valamint lehetséges szlovák partnerek felkutatása.

Folytatni kell a regionális konjunktúrakutatási program marketing tevékenységét, hiszen a mintaprogram akkor lesz müködöképes, ha a lekérdezések folyamatosan megismételhetők. A program nagyobb mértékủ elterjesztése azonban legalább kéthárom sikeresen lefuttatott program referenciáival biztosítható. Éppen ezért a potenciális vásárlókon, a piac megnyerésén túl újabb pályázati források (OMFB, Kereskedelemfejlesztési elöirányzat, PHARE CBC, megyei területfejlesztési alapok stb.) elnyerése is szükséges.

A pályázati források a program továbbfejlesztését (pl. szoftvere fejlesztés, hardver háttér minőségi javítása) a publikációk, konjunktúra jelentések megjelenítési minöségének fejlesztését, az eladhatóság növelését szolgálhatják.

Egy másik irány lehet a regionális konjunktúrakutatás kiterjesztése a határok túlsó felére egy körvonalazódó Bécs-Pozsony-Györ eurorégiós program keretében. Első lépésben a már múködő osztrák regionális konjunktúrakutatással való kompatibilitás és közös jelentések kiadása lenne megvalósitható. Következỏ lépésben pedig egy know-how program keretében - egy szlovák partner bevonásával - a szlovák határmentére is kiterjeszthetők a felmérések és elemzések.

\section{Jegyzetek}

1 KSH CIM-KE számítógépes adatbázis 1995. december 31-i állapot. Az adatbázis csak jogi személyiségủ szervezeteket tartalmaz.

2 KSH CIM-KE számitógépes adatbázis 1995. december 31-i állapot. Az adatbázis csak jogi személyiségủ szervezeteket tartalmaz.

${ }^{3}$ Megj.: amit a kormányzati politikától fủggỏ tényezőknél már elemeztünk.

${ }^{4} \mathrm{Az}$ értékelés ơtfokozatú skálán tơrtént; az 5-ös oszályzat a legfontosabb, míg az 1-es a legkevésbé lényeges kategóriákat jelenti. 